next), and in a different climate, it may be easier to tell what space science is for: like the rest of science, it is for understanding part of what the natural world is all about. To say this is not to say that science has no practical function (because the opposite is true), but merely that the more usual practical benefits are often accidental. Leadership, whatever it may mean, may be among them, but is usually a second-order accident.

\section{Is 1992 already here?}

The European Commission is behaving as if Europe were already a single market.

ThE European Communities, often mis-named "the Common Market", seems to have had a rush of rich red blood to the head in the past few weeks. First, having last year warned European airlines that they would not be able indefinitely to continue their cosy cartel arrangements with each other, the European Commission has now written to them individually saying in clear terms what steps they will have to take to make legal their arrangements for restricting seat capacity on certain routes (and for sharing the revenues that result). Although the commission has not yet chosen to take the fateful step of saying that, at some predetermined stage, it will be illegal for a government to subsidize an airline, whereupon the true benefits of civil aviation technology will accrue in Europe as they already have elsewhere.

Meanwhile, the European Commission appears to be going after the telecommunications and broadcasting industries, even bigger and more promising fish for reform. The immediate issue concerns the standardization of the whole of the European industry: should there be a cellular radiotelephone network for the whole of Europe and, if so, by what standards should it be built and to whom should the work be contracted? The commission has a special brief under the terms of the Treaty of Rome to promote cross-cultural or transnational activities, and may fairly consider mobile cellular telephones to be one of them. The result is that the commission is busily encouraging the standards by which the same mobile telephones might be made to function in places as different as France, Greece, Holland and Ireland. More daring still, it is also talking to manufacturers in almostopen committee meetings about their capacity to supply all that equipment, or to operate pan-European networks.

The good news is that this attitude appears to be infectious, for technical as well as psychological reasons. There is no point in owning a mobile Eurotelephone, incurring in the process the obligation to pay an annual membership fee, without being able to call up people not already as privileged. So the commission, no doubt encouraged by the support of the people who reckon they would make fortunes from building even a fraction of the new equipment, has taken to saying that its scheme will not succeed unless cellular Eurotelephones have access to the telephone lines at present owned and operated by the great public monopolies, of which the Deutches Bundespost is the largest, the most conservative and the most expensive. But everybody knows that right of access to a monopoly's assets is the death of that monopoly. (It might well be cheaper for West Germans to carry mobile telephones in their pockets than to use their monopoly's connections between their fixed instruments.) Those who relish the maxim that the grandest are those who have the furthest to fall may confidently await the ending of that anachronism.

\section{Protectionism}

The snag is that a long time may have to pass. The European Commission is just now buoyed up by its belief that "everything" will be different after 1992; much will be, but not everything. Moreover, the commission's own case is weakened by its Eurochauvinism. While the commission is talking to European manufacturers about the supply of new telecommunications services, it cold-shoulders manufacturers from elsewhere (not unconnected with the fact that the US House of Representatives passed another restrictive trade bill last week). Japanese companies are among other potential suppliers. Are they being given a chance to make their pitch and, if not, why not? Even from a chauvinist point of view, the commission should pay some attention to the question of whether it seeks efficient services so that Europeans can do other things, or whether it needs the business (in which case, agriculture might have to go to the wall).

Broadcasting is more difficult and contentious. The commission's theoretical position is that it is required to promote pan-European standards (relative decibels between transmitters and receivers, for example, or how many minutes of advertisements there should be in any hour of television broadcasts), while nursing its predilection for competition. The commission would be well advised to acknowledge that its gargantuan twovolume consulation document on the issues, published two years ago, was read by very few and understood only by a minority among them. The trouble with television (as distinct from telephones) is that different kinds of people take it to heart. If the European Commission is determined to behave as if 1992 were here already, it had better be discriminating about the causes for which it would go to the stake.

\section{Money problems multiply}

A popular view of the world's money problem is that nothing much has changed. Is that correct?

"STEADY as she goes" is an old seafarer's saying most often intoned with particular urgency when ships are about to hit the rocks. The irony is nicely embodied in the communiquee put out by the Group of Seven (familiarly known as G-7) at the end of its meeting in Washington some three weeks ago; it can have been only cruel bad luck that it should have announced that all is well with the world's finances on the eve of the announcement that the US trade balance had unexpectedly worsened. Things have been in turmoil ever since - but they had been in turmoil for some time before that, so that the most recent events make very little difference.

Enough has been said about the US federal government's domestic deficit, which cannot in any case be reduced before the US elections early in November. Events could go awry between now and then, but only in such a way a to shuffle people's electoral chances. The most effective cause would be a second poor month, but that is against the odds; it is unthinkable that such a cheap dollar would not help to sell dollar-denominated goods.

The substantial worries for the next half year lie elsewhere, and are most prudently put as questions. Japan, suddenly discovered to be the most prosperous nation on the surface of the Earth, remains a curious mixture of conservative agrarian and devil-may-care urban sustained in its expectations of the future only by its cheerful experience of the past quarter of a century; can that last? West Germany, once the West's miracle of enterprise, seems to have lapsed into book-keeping; is that intentional and, if so, who intends it? Britain, quite recently the sick man of Europe, chose to beat double-digit inflation by being tough and is now assiduously running a supply-side economy by fiscal devices for allowing house prices to leap ahead against the wishes of the Chancellor of the Exchequer; just when will those chickens come home to roost? The fact that the poor countries are even more short of funds than before the West's banks became prudent, declining to add to their loan books, was easily predicted; but does this mean that there is now no hope for the people now thoroughly ground down? That there is continuing trouble in the Middle East is almost neither here nor there. What the world needs is a way of running its finances with ingredients other than illusions. 